\title{
The differing role of weather systems in southern Australian rainfall between 1979-1996 and 1997-2015
}

\author{
Acacia S. Pepler ${ }^{1}$ D $\cdot$ Andrew J. Dowdy ${ }^{1} \cdot$ Pandora Hope $^{1}$
}

Received: 8 June 2020 / Accepted: 14 December 2020 / Published online: 2 January 2021

(c) Crown 2021

\begin{abstract}
Most of the rainfall in southern Australia is associated with cyclones, cold fronts, and thunderstorms, and cases when these weather systems co-occur are particularly likely to cause extreme rainfall. Rainfall declines in some parts of southern Australia during the cool half of the year in recent decades have previously been attributed to decreases in the rainfall from fronts and/or cyclones, while thunderstorm-related rainfall has been observed to increase, particularly in the warm half of the year. However, the co-occurrence of these systems, particularly the co-occurrence of cyclones or fronts with thunderstorms, can be very important for rainfall in some areas, particularly heavy rainfall, and changes in the frequency of these combined weather systems have not been previously assessed. In this paper we show that the majority of the observed cool season rainfall decline between 1979-1996 and 1997-2015 in southeast Australia is associated with a decrease in the frequency of fronts and cyclones that produce rainfall, while there has simultaneously been an increase in the frequency of cold fronts and thunderstorms that do not produce rainfall in some regions. Thunderstorm rainfall has increased in much of southern Australia, particularly during the warm half of the year, including an increase in rainfall where a thunderstorm environment occurs at the same time as a cyclone or front.
\end{abstract}

Keywords Cyclone $\cdot$ Front $\cdot$ Thunderstorm $\cdot$ Change $\cdot$ Australia $\cdot$ Midlatitude

\section{Introduction}

Southern Australia is located at the equatorward edge of the midlatitude storm tracks, where annual rainfall is dominated by the passage of rain-bearing fronts and cut off lows, particularly during the cooler months of the year (Pook et al. 2011, 2014; Risbey et al. 2009). Thunderstorms are also important for rainfall in this region, particularly during the warmer months, as well as the cooler months in parts of the eastern seaboard (Dowdy 2020; Dowdy and Kuleshov 2014), and the co-occurrence of fronts, cyclones and thunderstorms is particularly important for the most extreme rainfall totals (Dowdy and Catto 2017; Pepler et al. 2020).

In recent decades, cool season rainfall has declined in parts of southern Australia, with large decreases since the late 1960s in southwestern Western Australia (Hope et al. 2006) and a significant drought between 1997 and 2009 in

Acacia S. Pepler

acacia.pepler@bom.gov.au

1 Australian Bureau of Meteorology, Melbourne, Australia southeast Australia (Murphy and Timbal 2008; Timbal and Drosdowsky 2013). These declines have previously been attributed to a number of causes, including a long-term intensification of the subtropical ridge (Timbal and Drosdowsky 2013) and poleward expansion of the Hadley Cell (Nguyen et al. 2015) as well as an increase in the proportion of the time influenced by anticyclonic conditions in the southeast (Pepler et al. 2019). Increasing levels of atmospheric greenhouse gases have contributed to changes in Southern Hemisphere circulation including the intensifying subtropical ridge, playing a role in recent rainfall declines in southeast Australia (Rauniyar and Power 2020; Timbal et al. 2010) and southwest Australia (Timbal et al. 2006).

The contributions of changing synoptic types to rainfall changes has also been investigated for parts of these regions. Cool season rainfall declines in southeast Australia between 1956-2009 have been attributed primarily to a decrease in the rainfall arising from cut-off lows, with a smaller proportion of the decline arising from a decrease in the average rainfall per frontal system (Risbey et al. 2013a). Fronts were found to play a stronger role in winter rainfall declines in southwest Australia (Risbey et al. 2013b), although there 
are no statistically significant trends in frontal frequency in either western Australia (Hope et al. 2014) or the Southern Hemisphere (Rudeva and Simmonds 2015). While these studies have provided useful insights into the synoptic systems influencing rainfall change, they typically classified events into either a front or a cut-off low, and have not considered cases when these systems co-occur, which can lead to more significant impacts (Dowdy and Catto 2017).

Thunderstorms also make an important contribution to rainfall in southern Australia, particularly during the warmer months. Dowdy (2020) identified significant increases over recent decades in convection-related rainfall through many parts of Australia, including large increases in the intensity of rainfall per thunderstorm. Additionally, that paper also indicated an increase in southeast Australia in the frequency of thunderstorms that produce little rainfall ('dry thunderstorms'), (Dowdy and Mills 2012). An increase in atmospheric moisture associated with the observed warming trend has also been associated with an increase in the frequency of thunderstorm-related extreme rainfall, which is expected to continue into the future (Barbero et al. 2018; Guerreiro et al. 2018; Osburn et al. 2020).

A new dataset of the synoptic systems influencing Australian weather has recently been developed for 1979-2015 (Pepler et al. 2020), which objectively identifies the occurrence of cyclones, cold fronts, thunderstorms, as well as when multiple systems co-occur. Using this dataset, we can assess how changes in cyclones, cold fronts, thunderstorms, as well as their interactions, have contributed to changes in southern Australian rainfall between 1979 and 2015. In addition, we decompose the change in rainfall from each weather type to the change in rainfall arising from changes in the frequency and the intensity of the system, allowing us to identify which factors are most important for different seasons and regions in southern Australia.

\section{Data}

The weather types dataset used here is described in detail in Pepler et al. (2020), and is based on the approach used in Dowdy and Catto (2017). Briefly, we combine two datasets of cyclone tracks, each of which were run for 1979-2015 using 6-hourly $0.75^{\circ}$ MSLP fields from the ERA-Interim (ERAI) reanalysis (Dee et al. 2011). While this is an older reanalysis, which has now been superseded by the higherresolution ERA5 reanalysis (Hersbach et al. 2020), the new reanalysis was not available when the component datasets were developed. This paper focuses on results for Australia south of $25^{\circ} \mathrm{S}$, as the methods used for identifying cyclones and fronts are more effective at identifying midlatitude weather systems than they are in the tropics (Pepler et al. 2020).
Cyclone centres were identified using the University of Melbourne cyclone identification and tracking scheme (Murray and Simmonds 1991; Simmonds et al. 1999), and cyclone areas enclosed within a closed contour were identified using the Wernli and Schwierz (2006) method. These are combined to give a dataset of "Confirmed cyclones", where a cyclone region contains a cyclone centre identified using the Murray and Simmonds (1991) method. A $5^{\circ}$ radius of influence is then added to capture all rainfall associated with the cyclone, which is slightly larger than the $3^{\circ}$ area used in Dowdy and Catto (2017) but was chosen in order to capture all rain associated with the cyclone region based on previous composite studies (e.g. Hawcroft et al. 2012). The Murray and Simmonds (1991) method is also used to identify surface anticyclones, with a $10^{\circ}$ area of influence.

We also use two distinct datasets of cold fronts, also run using ERAI. The approach of Simmonds et al. (2012) and Rudeva and Simmonds (2015) approach identified cold fronts based on a shift in the $10 \mathrm{~m}$ wind direction from a northwesterly to southwesterly quadrant. Cold and warm fronts are also identified using the thermal front parameter calculated from the ERAI $850 \mathrm{hPa}$ wet bulb potential temperature (Berry et al. 2011; Catto et al. 2012a). A $5^{\circ}$ radius of influence is added to all fronts to identify front-related rainfall, consistent with similar studies (Catto et al. 2012a; Dowdy and Catto 2017), with "Confirmed cold fronts" identified where the areas detected using both cold front methods overlap.

We also employ a new dataset of thunderstorm environments for Australia (Dowdy 2020). This dataset is based on the thunderstorm parameter (CAPE*S06 ${ }^{1.67}$ ) as calculated from the ERAI convective available potential energy (CAPE; using the most unstable level based on maximum equivalent potential temperature) and bulk wind shear from 0-6 km (S06). The dataset was calibrated against two observed lightning products to identify local thresholds that give the same annual thunderstorm frequency as observed. Application of the method to every $0.05^{\circ}$ grid cell throughout Australia between 2005 and 2015 results in a Probability of Detection of approximately $50 \%$ in identifying observed lightning events. The False Alarm Ratio and the fraction of missed lightning events from the total number of lightning events are also approximately 50\% across Australia, noting that as thunderstorms are small in scale it is common for only small parts of a region to experience lighting even when conditions are favourable. These verification statistics as detailed in Dowdy (2020) demonstrate that this dataset of thunderstorm environments performs well against observations. While thunderstorm environments are most common in the warmer months, they can occur at any time of year, with wind shear playing a larger role in some low-CAPE environments during the cooler months of the year (Dowdy et al. 2020). 
These four datasets are combined to create a 6-hourly, $0.75^{\circ}$ resolution grid across Australia that classifies each point into one of eight categories (Table 1), with a focus on the intersections between cyclones, fronts and thunderstorms following the approach of Dowdy and Catto (2017). In this study, the co-occurrence of a cyclone and front $(\mathrm{CF})$ requires a gridpoint to have been influenced by both a cyclone area and a front area on the same day; the front-only and frontthunderstorm types will in many cases be trailing fronts associated with an extratropical cyclone on the poleward side, as is common in the extratropical storm tracks (Bjerknes and Solberg 1922).

The seven main weather types collectively explain $91 \%$ of total rainfall in southern Australia (Pepler et al. 2020), noting that there are a large number of different ways of identifying weather systems that will overlap between studies. For instance, the methods used in this paper may incorrectly identify a low pressure trough as a cold front, and many cold fronts may be associated with other systems such as atmospheric rivers and Northwest Cloudbands (Reid et al. 2019). Similarly, many surface lows will also be associated with a strong upper-level system such as a cut-off low, particularly those which produce heavy rainfall (Dowdy et al. 2013; Pepler and Dowdy 2020; Pook et al. 2006), and warm conveyer belts can play an important role in the generation of rainfall from fronts and cyclones (Catto et al. 2015; Madonna et al. 2014). The "Other" category can be further subdivided into days with high pressure systems $(\mathrm{H})$, warm fronts (WF), cyclones or fronts that are identified by a single method (Unconf), and remaining undefined days (Undef), resulting in a total of 11 types.

Rainfall analyses use the Australian Water Availability Product (AWAP) daily rainfall grids for Australia at $0.05^{\circ}$ resolution (Jones et al. 2009). Note that data in the central north-west of the country has few stations contributing to the gridded product, and results can be less reliable in that region (King et al. 2013). Each synoptic system dataset is first aggregated across the four observations at 0000, 0600, 1200 and 1800 UTC before regenerating a daily version of the combined weather types, which results in a general increase in the frequency of the combined weather types and a decrease in undefined days, although the overall spatial characteristics for each type are similar to those using 6-hourly data (Pepler et al. 2020).

The rainfall recorded at 9 a.m. local time ( 2300 UTC) at each gridpoint is then attributed to the nearest weather type from the ERAI gridded data, which is identified by converting each weather type to a $0 / 1$ flag and bilinearly regridding to the AWAP resolution. This allows us to identify important spatial features of rainfall, such as the influence of topography, while linking local rainfall to broader-scale synoptic patterns.

Assessing change can be achieved by examining trends, however, given that the breadth of weather types reduces the number of events in each type, a comparison of two periods will be more robust. The period from 1979-2015 divides at 1996/7 into two periods of 18 and 19 years. The year 1997 also aligns with a further downturn in rainfall in the late 1990s in south-west Western Australia and the start of the Millennium Drought in south-east Australia, which is considered by some to have ended with the 2010-2012 La Niña but by others to continue into the present (Rauniyar and Power 2020). We thus assess the changes in rainfall and weather systems between 1979-1996 and 1997-2015, and identify statistically significant changes using a twosided Student's $t$ test for $\mathrm{p}<0.05$. To check the robustness of results to this choice of start year, in some cases we add additional comparisons by instead dividing at 1995/1996, $1997 / 1998$, or comparing the period 1980-1999 with 2000-2015. These make little difference to results for SEA and SWWA which have experienced strong cool season declines, but the choice of start year is more important for trends in smaller regions such as Tasmania (TAS) and the Eastern Seaboard (ESB).

The changes seen in Australian rainfall over the last few decades are quite different in the cool season compared to the warm season in many places (Bates et al. 2008; Hope et al. 2017), and thus two six month seasons (May-October
Table 1 Description of weather types used in this paper, following Dowdy and Catto (2017)

\begin{tabular}{lll}
\hline Name & Long name & Description \\
\hline CO & Cyclone-only & A cyclone/low is present in both datasets \\
FO & Front-only & A cold front is present in both datasets \\
TO & Thunderstorm-only & A thunderstorm environment is present \\
CF & Cyclone-Front & Both a cyclone and a cold front are present \\
CT & Cyclone-Thunderstorm & Both a cyclone and a thunderstorm environment are present \\
FT & Front-thunderstorm & Both a cold front and a thunderstorm environment are present \\
CFT & Triple storm & A cyclone, cold front, and thunderstorm are all present \\
Other & Other & Days with Highs (H), Warm Fronts (WF), Fronts or Lows identi- \\
& & fied by only one method (Unconf) and when no weather system is \\
& & defined (Undef) \\
\hline
\end{tabular}


and November-April) are considered in this study. Results are broadly comparable if we instead define the cool season as April-September or April-October (not shown). As well as showing spatial changes, we also show changes for four key regions (Fig. 1): southwestern Western Australia (SWWA) and southeast Australia (SEA), which have experienced long-term cool season rainfall declines (Hope et al. 2006; Rauniyar and Power 2020; Timbal et al. 2006, 2010); the eastern seaboard (ESB), where rainfall influences and trends differ from elsewhere in SEA (Dowdy et al. 2015; Pepler et al. 2014; Timbal 2010), and Tasmania, which is located in the main midlatitude storm tracks with distinctly different projected future changes (Hope et al. 2015).

The change in rainfall from each weather type can be further decomposed into the change resulting from a change in the overall weather-type frequency $(\Delta \mathrm{f})$, and the change resulting from a change in the average rainfall per system $(\Delta \mathrm{r})$ (e.g. Hassim and Timbal 2019). The rainfall change due to a change in frequency of a given weather type can be calculated as $r_{1} \times \Delta f$ : the multiple of the absolute change in the seasonal mean number of days $(\Delta f)$ and the average rainfall expected per day for that weather type during the first period $\left(\mathrm{r}_{1}\right)$. The difference between this and the total change is considered to arise from changes in the mean rainfall per weather system, noting that these two components can have opposite signs in some cases. This is a simplified version of the approach used in Catto et al. (2012b), as the contribution to rainfall declines arising from the interaction between frequency and intensity is very small compared to the other two terms.

These two components are first calculated both across all days with a weather type, which includes some days with no rainfall. We also repeat this process for just the subset of days where at least $1 \mathrm{~mm}$ of rainfall is recorded, as at least $95 \%$ of annual rainfall falls on these days. This allows us to distinguish the changes in the overall frequency of weather systems from changes in the number of rain days associated with a given system, as these trends can differ. In addition, we separately assess changes in the number of dry days $(<1 \mathrm{~mm}$ ), rain days (all days $\geq 1 \mathrm{~mm}$ ) and moderate rainfall days $(>=10 \mathrm{~mm})$ associated with each weather type. The gridded rainfall data is considered adequate for examining moderate rainfall extremes of this nature (King et al. 2013).

\section{Results}

Figure 1 shows the change in the average rainfall for each season between 1979-1996 and 1997-2015. Broadly, rainfall has declined across much of southern mainland Australia during the cool season (May-October), and rainfall has increased in the northern tropics during the warm season (November-April). Averaged across four regions of interest in southern Australia, there is a statistically significant decline of $50 \mathrm{~mm}(16 \%)$ in southeast Australia (SEA) during the cool season. There is also a decline in cool season rain in SWWA of $28 \mathrm{~mm}(9 \%, \mathrm{p}=0.09)$, predominantly due to a $31 \mathrm{~mm}(16 \%)$ decline during May-July $(\mathrm{p}=0.01)$, noting that our period of analysis begins after rainfall declines in SWWA first began in the 1960s (Hope et al. 2010). In comparison to elsewhere in southern Australia, there is little change between the two periods in Tasmania (TAS) or averaged across the eastern seaboard (ESB).

During the warm season (November-April) there have been large increases in rainfall across northern Australia, which extends into much of mainland southern Australia, as
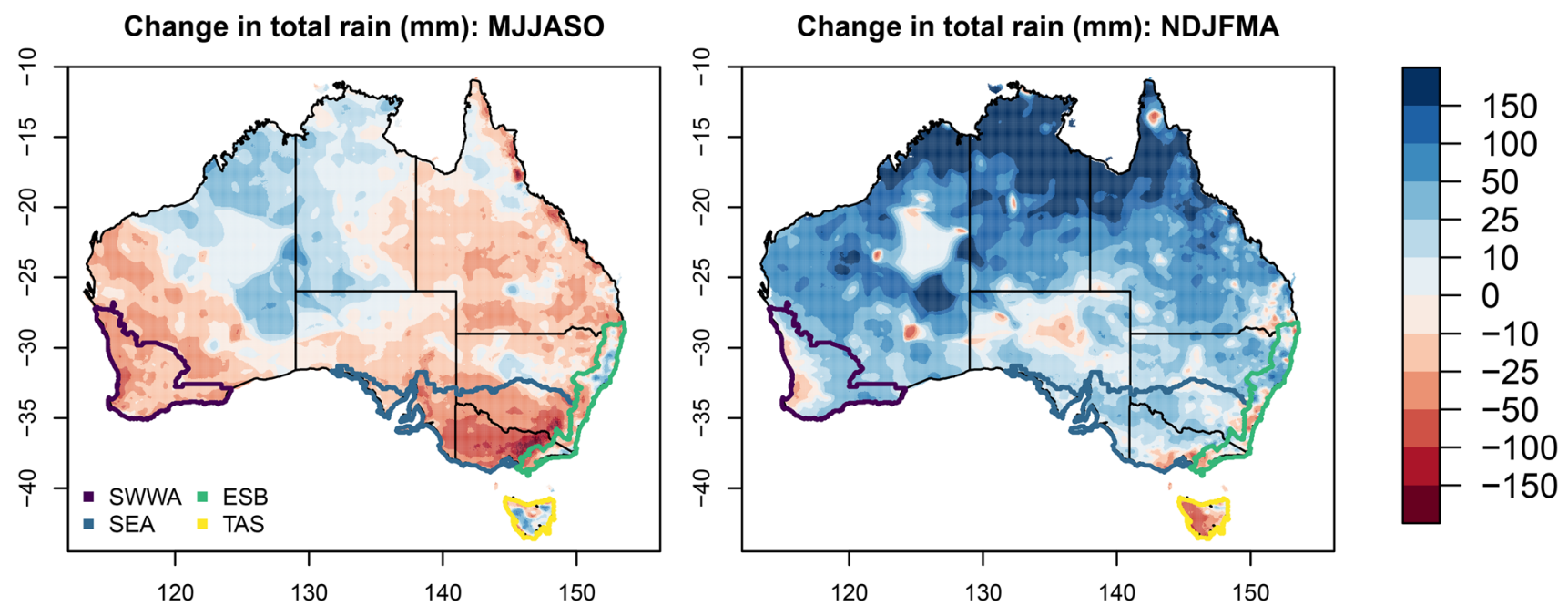

Fig. 1 May-October (cool season: left) and November-April (warm season: right) rainfall change (in mm) between 1979-1996 and 1997-2015 for Australia, with four regions of interest marked with coloured contours 
well as decreases in rainfall in Tasmania, although changes are not statistically significant in any of our four subregions.

\subsection{May-October rainfall change}

The decline in total May-October rainfall across southern Australia can be separated into the rainfall associated with each of the 11 weather types (Fig. 2). There is a widespread decrease in cool season rainfall associated with cyclones and fronts $(\mathrm{CO}, \mathrm{FO}$ and $\mathrm{CF})$, with a decline in $\mathrm{CT}$ rainfall on the Great Dividing Range near the east coast and much of inland southeast Australia contrasting with pockets of increases along the coastline. In contrast, changes in cool season thunderstorm-related rainfall are mixed, with some areas of increases in rainfall from TO, FT and CFT types, particularly in the east and Tasmania. The total rainfall from the four other types is generally small (Pepler et al. 2020), with the highest contribution to seasonal rainfall arising from high pressure systems, which produce $6 \%$ of rainfall in Australia south of $25^{\circ} \mathrm{S}$. This is a consequence of the very large frequency of high pressure systems during this season (33\% of days), as their mean daily rainfall is the smallest of any weather type, with rainfall typically only recorded in the outer edges of the high, particularly in cases where the high is small or directs moist onshore winds into coastal regions. The overall changes in rainfall from these four types are correspondingly small (Fig. 2h-k). Consequently, the majority of the paper will focus on the seven main rain-bearing weather types, with the other four types clustered together and termed 'Other'.

Aggregated across SEA, there are statistically significant declines in the rainfall from $\mathrm{CO}, \mathrm{FO}$ and $\mathrm{CF}-$ related types in the cool season (Fig. 3), with a $27 \%$ decline in the total rainfall associated with these types $(\mathrm{p}<0.01)$, which is statistically significant for all start years. This is due to a decrease in both the frequency and the intensity of CO days, while the change in frontal rain is dominated by a decrease in intensity. SEA also recorded a decrease in the intensity of rainfall on Other days (Fig. 3), primarily due to a decrease in the average rainfall on days with high pressure systems (not shown). There is no statistically significant change in thunderstorm-related rainfall in SEA during this season.

In SWWA there is a statistically significant decrease in rain from the $\mathrm{CO}$ type, predominantly due to a decrease in the mean rainfall per $\mathrm{CO}$ day, but smaller declines in frontrelated types $\mathrm{FO}$ and $\mathrm{CF}$ during this period. SWWA also has a decrease in Other rainfall, driven by a decrease in the rainfall intensity on Other days.

The ESB and Tasmania also have decreases in nonthunderstorm rainfall ( $\mathrm{CO}, \mathrm{FO}$ and $\mathrm{CF})$ in recent decades, associated with both a change in frequency and intensity. The decline in total rainfall from these three weather types between 1979-1996 and 1997-2015 is 25\% in the ESB $(\mathrm{p}<0.01)$, which is robust to the choice of start year. There is a weaker $14 \%$ decline in rainfall from these systems in Tasmania ( $\mathrm{p}=0.04)$, which is not statistically significant if we choose different time periods (e.g. 1980-1999 vs 2000-2015). Declines in these regions are balanced by an increase in rainfall associated with thunderstorms, although this is generally not statistically significant, so there is no significant change in the total seasonal rainfall. Interestingly, there has been little change in the total number of cyclones and fronts in either region, but the proportion of those days which are also associated with thunderstorms has increased. In Tasmania the number of CFT days has increased from 7 to 9.2 days per season, resulting in a $36 \%$ increase in CFT rain,

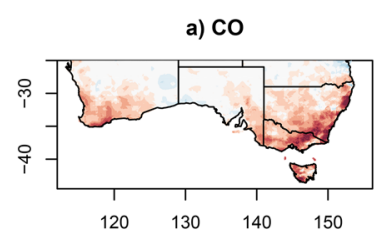

d) TO

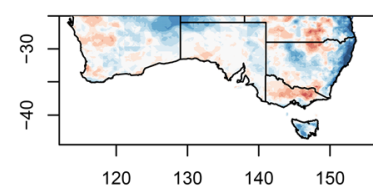

h) $\mathbf{H}$

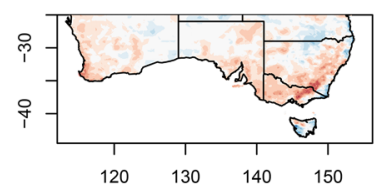

b) $\mathrm{FO}$

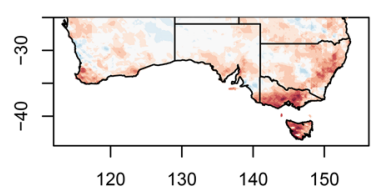

e) CT

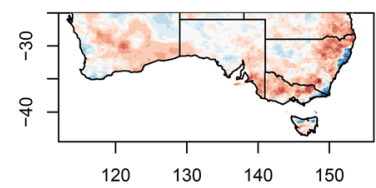

i) WF

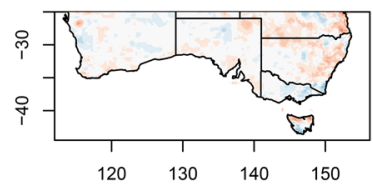

c) $\mathrm{CF}$

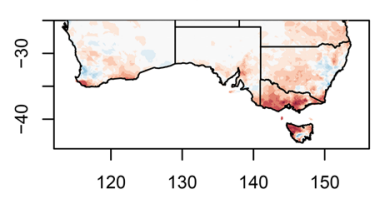

f) $\mathrm{FT}$

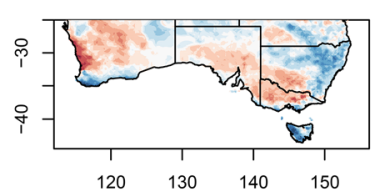

j) Unconf

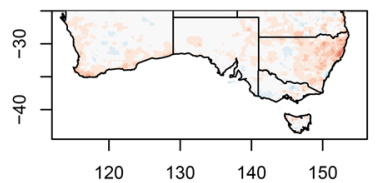

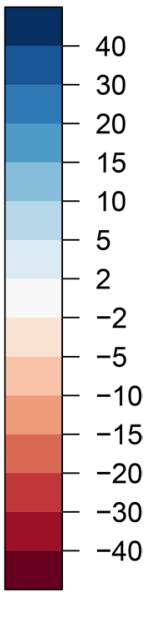

Fig. 2 May-October rainfall change (in mm) between 1979-1996 and 1997-2015 for the 11 weather types 
noting that CFT events have the highest average daily rainfall of any weather type in this season (Pepler et al. 2020).

Figure 4 shows, for each weather type, the change in the number of dry days (rainfall $<1 \mathrm{~mm}$ ) as well as the number of wet days $(>=1 \mathrm{~mm})$ and days with at least $10 \mathrm{~mm}$ of rainfall. Consistent with previous studies, there are large decreases in the number of $\mathrm{CO}, \mathrm{FO}$ and $\mathrm{CF}$ days that produce at least $1 \mathrm{~mm}$ of rain across most of southern Australia (Fig. 4i-k), with parts of the southeast experiencing more than 10 fewer rain days per year arising from these three weather types. Averaged across SEA there are 8.1 fewer rain days per season in recent decades, including 4.7 fewer rain days from the $\mathrm{CO}, \mathrm{FO}$ and $\mathrm{CF}$ weather types, as well as a decrease in rain days from $O t h e r$ systems. There are also broad declines in the frequency of days with at least $10 \mathrm{~mm}$ of rain associated with these weather types (Fig. 4q-s), particularly in Victoria and western Tasmania, although these changes are not statistically significant. Interestingly, in SEA there is an increase in the total number of FO days despite a statistically significant $17 \%$ decrease in the number of FO days with rainfall, due to an increase in the number of FO days with no rainfall (Fig. 4b).

Thunderstorms are less common during the cool season, but most of southern Australia has seen an increase in the number of TO and FT days with rainfall totals below $1 \mathrm{~mm}$ (Fig. 4d, f). Changes in thunderstorms associated with rainfall are less spatially coherent, but there are indications of an increase in TO and FT rain days on parts of the south and east coasts (Fig. 41, n), as well as an increase in CFT days associated with rainfall in Tasmania (Fig. 4o), but decreases in these types further inland. Spatial patterns of changes in $10 \mathrm{~mm}$ days and $25 \mathrm{~mm}$ days (not shown) are broadly consistent with $1 \mathrm{~mm}$ days, with parts of western Tasmania experiencing one additional CFT day with at least $10 \mathrm{~mm}$ of rainfall per year in the recent period.
Fig. 4 Change in the average number of days of each weather type in May-October between 1979-1996 and 1997-2015 separated by rainfall rate: $<1 \mathrm{~mm}$ rainfall (left), $\geq 1 \mathrm{~mm}$ of rainfall (middle), $\geq 10 \mathrm{~mm}$ of rainfall (right). Colours are only shown where there is an average of at least 0.2 days/year in the $1979-1996$ period, and $0.25^{\circ}$ of spatial smoothing has been added to make spatial patterns clearer

The stark difference in change in dry vs wet days for the front-related systems in Fig. 4b, j raises the question of whether the apparent decrease in the rainfall intensity of fronts and cyclones was primarily due to a decrease in the likelihood of a system producing rainfall, rather than the intensity of rainfall events. To assess this, in Fig. 5 we show the rainfall change separated into the proportion due to changes in the frequency of rain days from a weather system and the average rainfall intensity if rainfall occurs. Using this approach, the majority of the observed rainfall declines across southern Australia can be seen to result from a decrease in the frequency of cyclones and fronts that produce at least $1 \mathrm{~mm}$ of rain (Fig. 5d), with much weaker and more inconsistent changes in the average rain rate across all rain days. The weak increases in rainfall on the east coast from thunderstorms (TO and FT) are also primarily due to an increase in the frequency of thunderstorms associated with rainfall (Fig. 5h), although there is an increase in the mean rainfall on thunderstorm days on parts of the east coast, particularly TO days (not shown).

\subsection{November-April rainfall change}

During November-April, there is an increase in total rainfall across southern mainland Australia and a decrease in Tasmania (Fig. 1b), but the changes in total rainfall during this season are not statistically significant for any of our four subregions

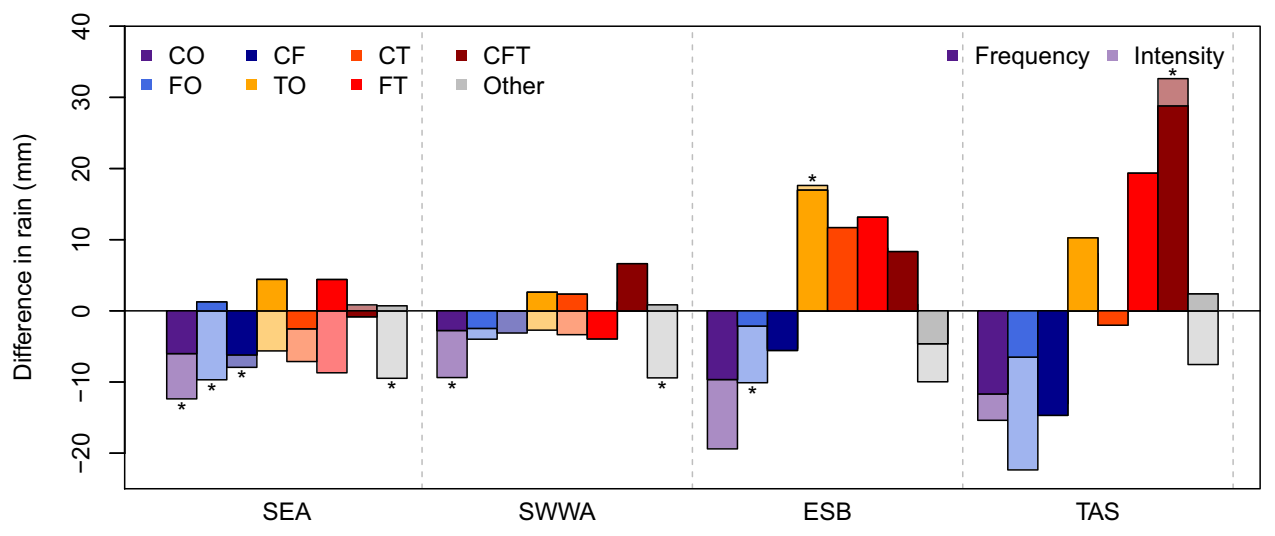

Fig. 3 Change $(\mathrm{mm})$ in average May-October rainfall between 19791996 and 1997-2015 for the four regions indicated in Fig. 1, separated into the seven main weather types and Other days. Darker shading indicates the portion of the change that would be expected from the change in frequency and lighter colours indicate the component from the change in rain rate, noting that where these oppose the total change is smaller. Changes with an asterisk (*) are statistically significant for $\mathrm{p}<0.05$ using a two-tailed $t$ test 

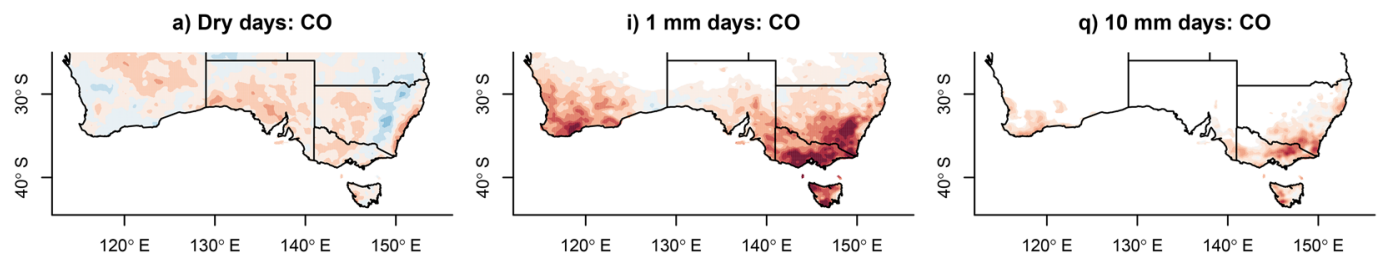

b) Dry days: FO

j) $1 \mathrm{~mm}$ days: FO

r) $\mathbf{1 0 ~ m m ~ d a y s : ~ F O ~}$
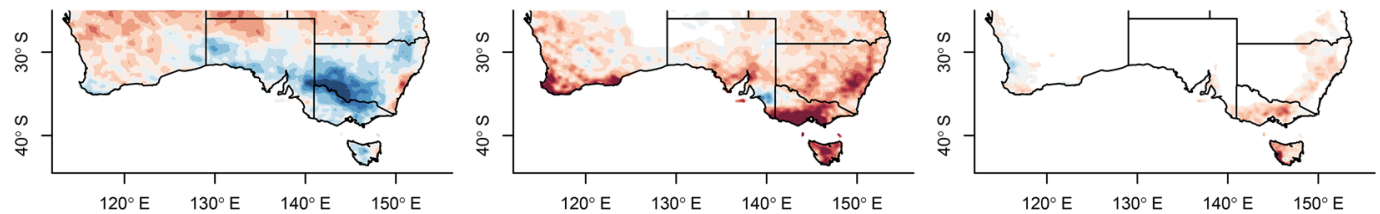

c) Dry days: $\mathrm{CF}$
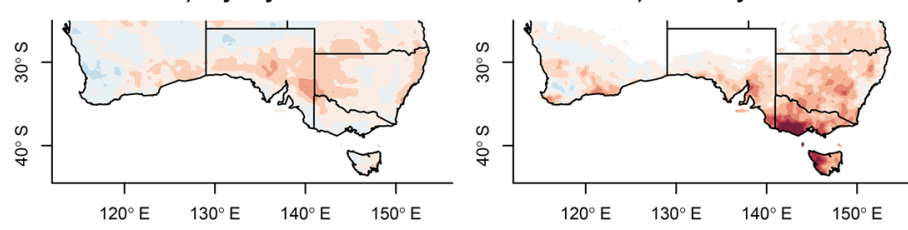

s) $10 \mathrm{~mm}$ days: $\mathrm{CF}$
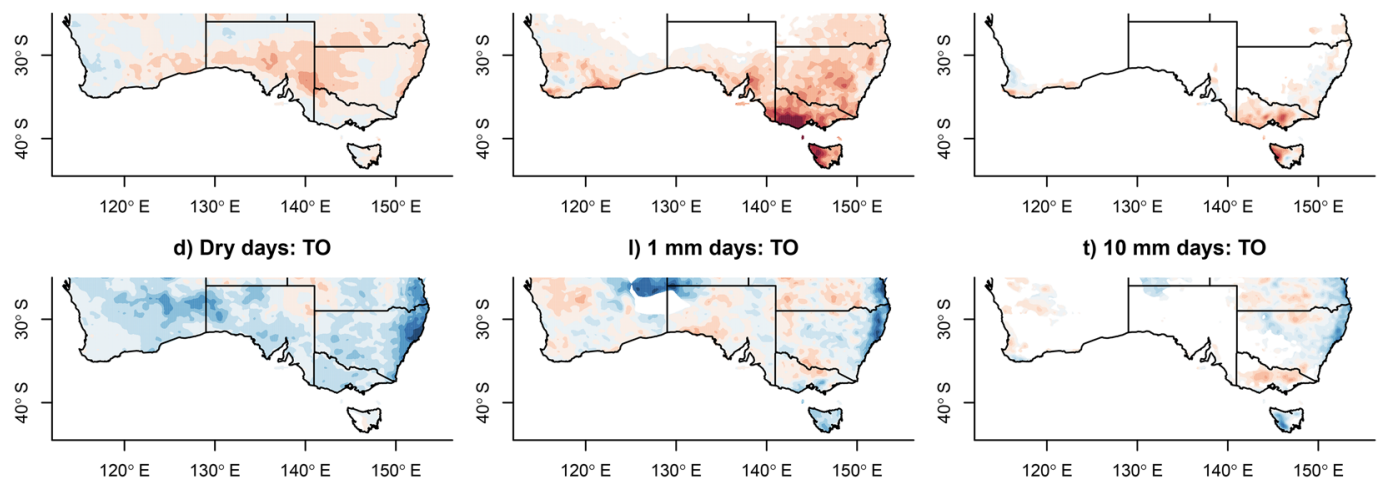

e) Dry days: CT

m) $1 \mathrm{~mm}$ days: CT

u) $10 \mathrm{~mm}$ days: CT
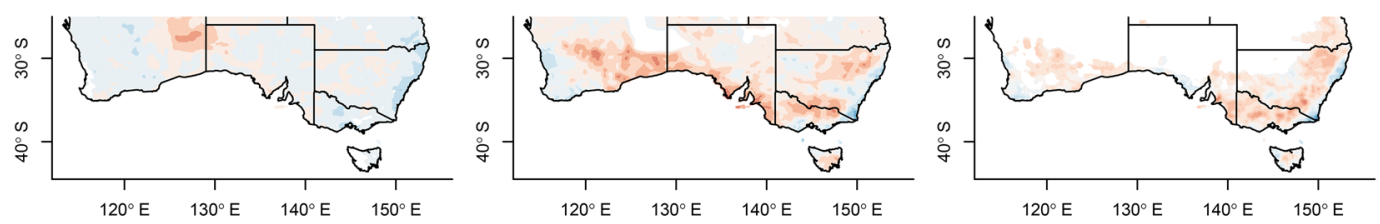

f) Dry days: FT

n) $1 \mathrm{~mm}$ days: FT
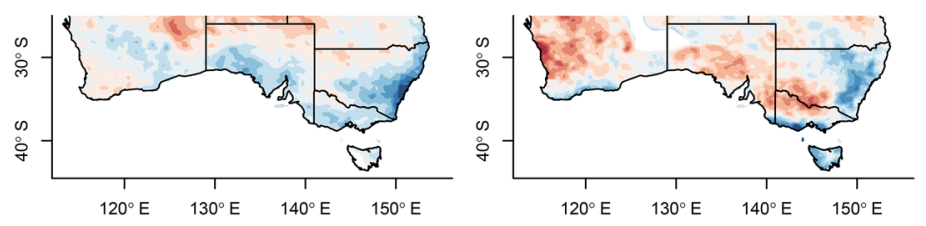

v) $10 \mathrm{~mm}$ days: FT

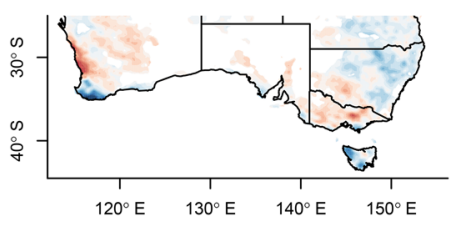

g) Dry days: CFT

o) $1 \mathrm{~mm}$ days: CFT
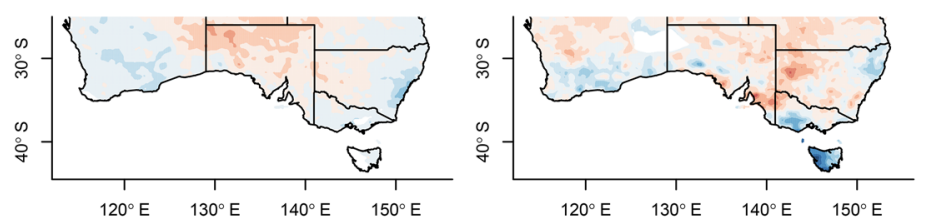

w) $10 \mathrm{~mm}$ days: CFT

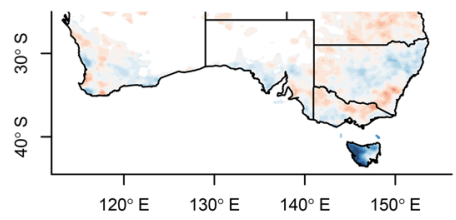

h) Dry days: Other

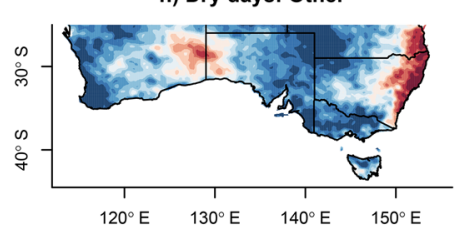

p) $1 \mathrm{~mm}$ days: Other

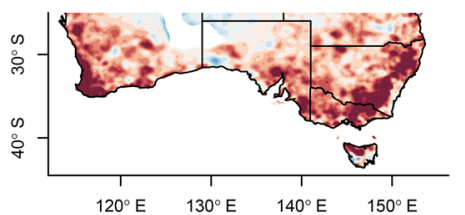

x) $\mathbf{1 0 ~} \mathrm{mm}$ days: Other
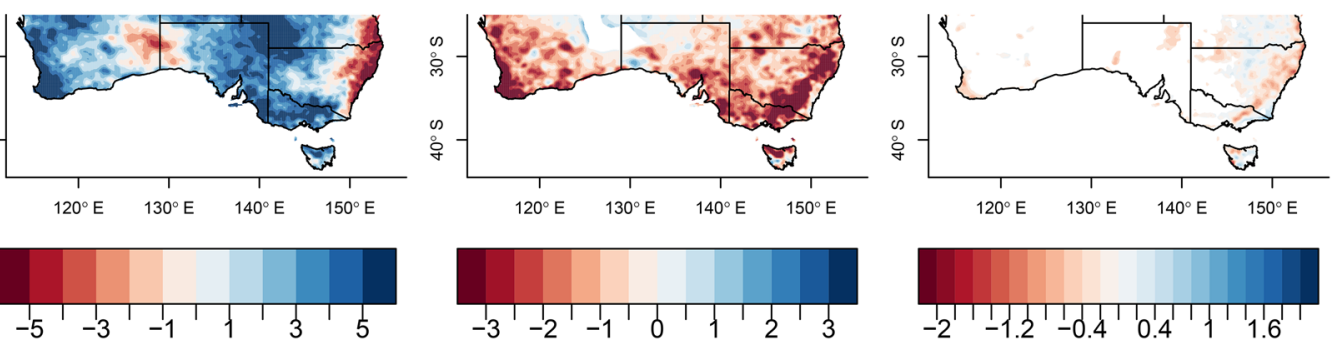

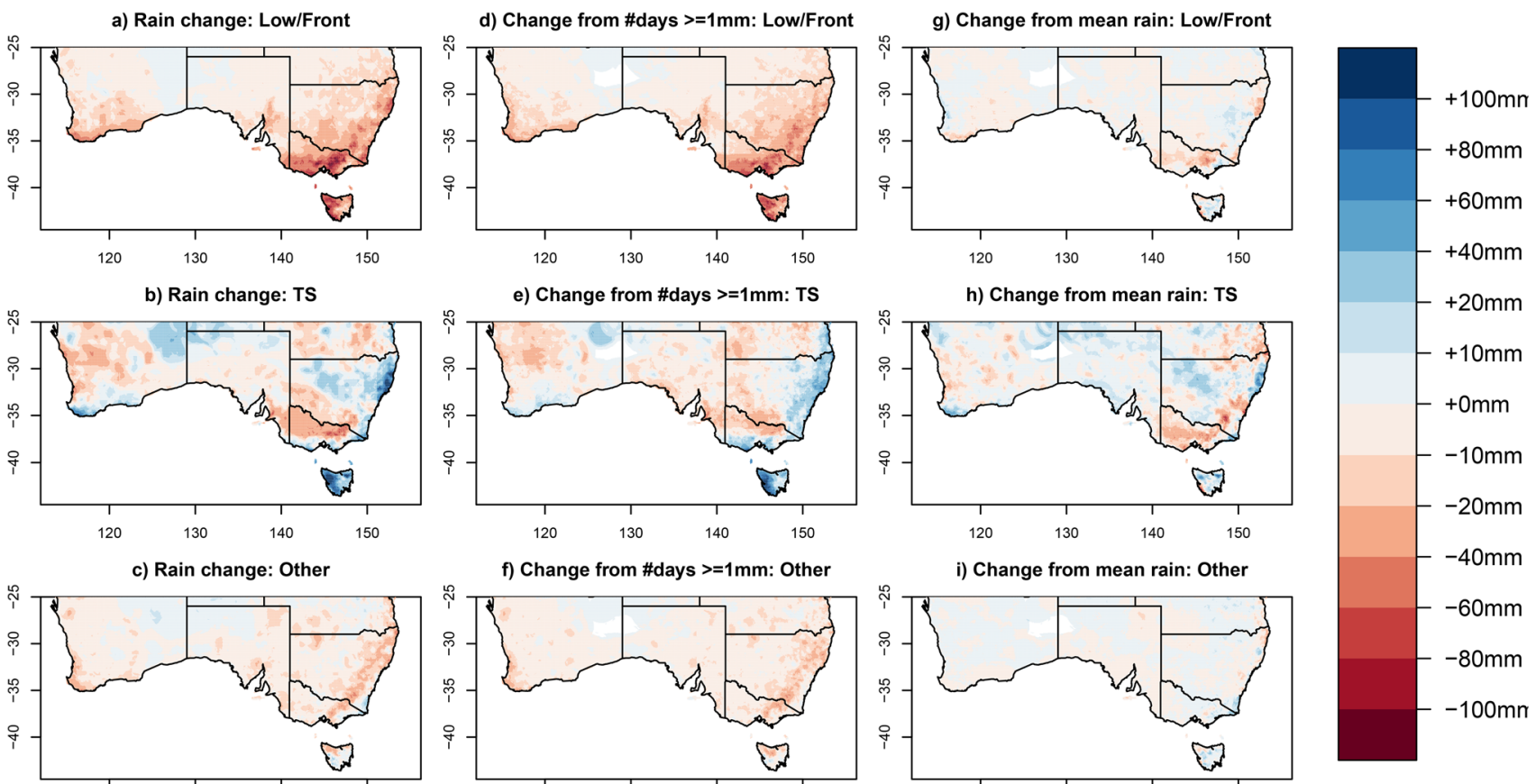

e) Change from \#days >=1mm: TS
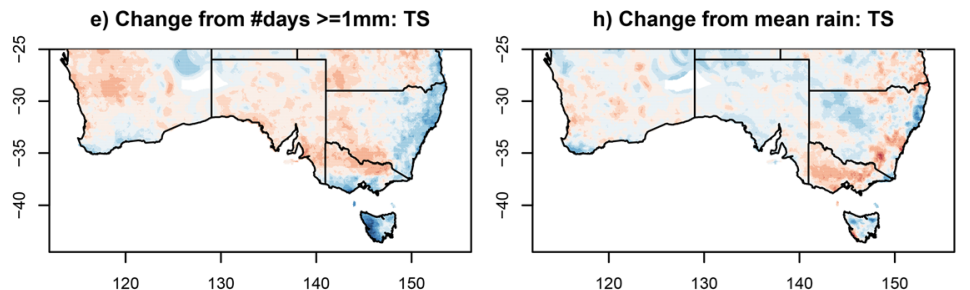

c) Rain change: Other

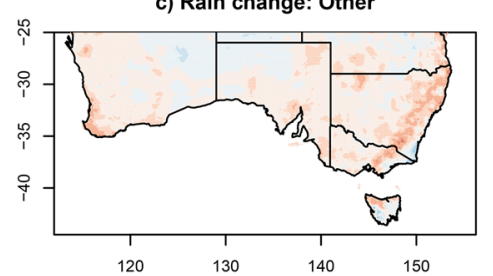

f) Change from \#days $>=1 \mathrm{~mm}$ : Other

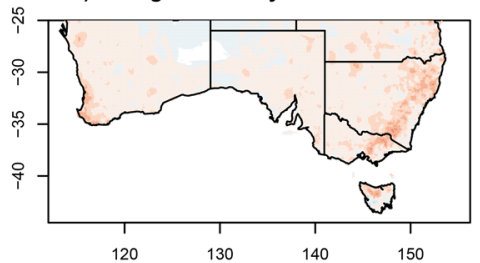

i) Change from mean rain: Other

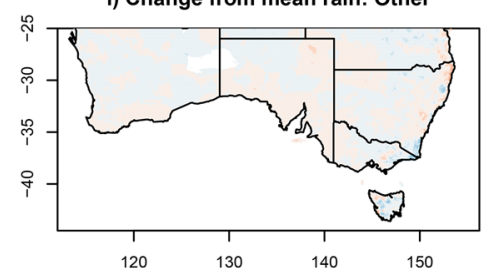

for the combined cyclone and front types $(\mathrm{CO} / \mathrm{FO} / \mathrm{CF}$, top), thunderstorm-related rainfall (TO/CT/FT/ CFT, middle) and Other rain (bottom) 1997-2015 (left column), and the change divided into components from the change in the frequency of $1 \mathrm{~mm}$ days (central), and from change in average rain rate on those days (right). Results are shown

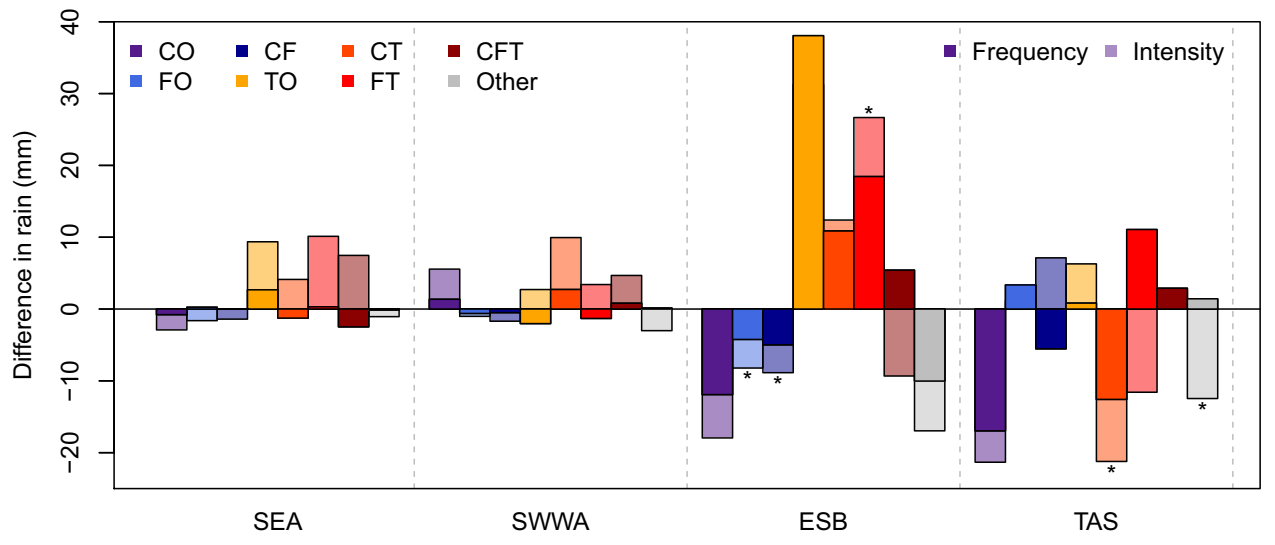

Fig. 6 Change $(\mathrm{mm})$ in average November-April rainfall between 1979-1996 and 1997-2015 for the four regions indicated in Fig. 1, separated into weather types. Darker shading indicates the portion of the change that would be expected from the change in frequency and

using a $t$ test. On the ESB, there is a statistically significant $37 \%$ decline in non-thunderstorm $(\mathrm{CO}, \mathrm{FO}$ and $\mathrm{CF})$ rainfall, but this is balanced by a statistically significant $18 \%$ increase in all thunderstorm-related rainfall, predominantly due to increases in the frequency of TO and FT days (Fig. 6). These differences are statistically significant for all start years, and the increase in thunderstorm-related rainfall is larger when lighter colours indicate the component from the change in rain rate, noting that where these oppose the total change is smaller. Changes with an asterisk $(*)$ are statistically significant for $\mathrm{p}<0.05$ using a two-tailed $t$ test

comparing 1980-1999 and 2000-2015 (+23\%). In contrast, in Tasmania there is a $13 \%$ decrease in cyclone-related rainfall during the warm season, particularly due to a decrease in rainfall from $\mathrm{CO}$ and $\mathrm{CT}$ days, but this is not statistically significant. Increases in the intensity of thunderstorm-related rainfall are also observed in SEA and SWWA, and increases in the intensity of cyclone-related rainfall in SWWA, although 
these are not statistically significant, noting that warm season rainfall is lower in these regions.

Consistent with results for the cool season, there is a decrease in the number of $\mathrm{CO}, \mathrm{FO}$ and $\mathrm{CF}$ days associated with rainfall across much of southern Australia during November-April (Fig. 7i-k). However, these weather systems make a smaller contribution to total rainfall during the warm season, where declines in rain days associated with these weather systems are balanced by increases in the number of rain days from TO and FT weather types (Fig. 71, $\mathrm{n}$ ), so there are no significant changes in the total number of rain days in SEA, SWWA or ESB. Large areas of the east also have 2 or more additional days where a TO or FT produces at least $10 \mathrm{~mm}$ of rainfall during recent decades (Fig. 7t, v), with on average 1.9 extra thunderstorm-related days with more than $10 \mathrm{~mm}$ of rainfall on the ESB in recent decades $(\mathrm{p}=0.03)$. This is consistent with results from Dowdy (2020), as well as observations of an increase in the frequency of extreme rainfall across southern Australia (Osburn et al. 2020). However, as the ESB also experienced a decrease in heavy rain events from cyclones and fronts, the overall change in days with at least $10 \mathrm{~mm}$ of rain is not statistically significant (+ 0.6 days).

Consistent with Dowdy (2020), during the warm season we see strong increases in the frequency of dry thunderstorms (notably TO and FT) across much of the southeast (Fig. 7d-g), particularly in the ESB, which can be a risk factor for bushfire ignition. There are also increases in the frequency of cold fronts that do not produce rainfall (FO and $\mathrm{CF}$ ) in inland areas of SEA (Fig. 7b, c).

When we combine all thunderstorm-related types (Fig. 8), there is an increase in thunderstorm-related rainfall across most of mainland southern Australia during the warm season, and this is a result of both an increase in the number of thunderstorm days associated with rainfall, as well as an increase in the average rainfall on thunderstorm days in many locations. In comparison, there is a decrease in rainfall from cyclones and fronts in the ESB and Tasmania, which is due to a decrease in the number of rain days from these weather systems rather than any change in intensity.

\section{Discussion and conclusions}

In southeast Australia, average cool season rainfall declined by $50 \mathrm{~mm}(16 \%)$ between 1979-1996 and 1997-2015. This decline is predominantly due to a decrease in rainfall from fronts and cyclones, and in particular a decrease in the frequency of cyclones and fronts that produce at least $1 \mathrm{~mm}$ of rain. This is consistent with earlier studies by Risbey et al. (2013a), who attributed two-thirds of the decline in cool season rainfall in southeast Australia between 1956 and 2009 to a change in both the frequency and intensity of cut-off lows, and one third of the decline to a decrease in the rainfall arising from cold fronts. Although this study identifies cyclones at the surface, those cyclones with the heaviest rainfall are likely to be associated with upper level cyclones such as cut-off lows, and further research will investigate the role of upper-level systems in declining cyclone rainfall in more detail.

Using computer-assisted methods to identify weather types over a long period of time allows for broad-scale studies such as this one. To assess the robustness of our results, we briefly compared our results with the weather types as identified by a trained synoptician on days with heavy rainfall at a particular location in western Victoria $\left(35.92^{\circ} \mathrm{S}\right.$, $142.85^{\circ} \mathrm{E}$ ) for the common period 1979-2009 (Pook et al. 2006; Risbey et al. 2009, 2013a, b). Although this study identifies cyclones at the surface, those cyclones with the heaviest rainfall are likely to be associated with upper level cyclones such as cut-off lows. For days with at least $10 \mathrm{~mm}$ of rainfall, $85 \%$ of the manually defined cut-off lows are associated with a low pressure system in our dataset, especially lows with a thunderstorm (CT/CFT, 62\%). Similarly, $84 \%$ of their frontal waves/fronts are identified here as a cold front, particularly a front combined with a thunderstorm (FT, 47\%). This brief comparison provides further confidence in the methods described here to faithfully represent these weather systems. Further research will investigate the role of upper-level systems in declining cyclone rainfall in more detail.

Consistent with global studies we found little change in the total frequency of cold fronts (Rudeva and Simmonds 2015), with a decrease in the frequency of rain-bearing fronts but an increase in the frequency of dry fronts in parts of southeastern Australia. There is also a statistically significant decrease in the average rainfall from high pressure systems, consistent with the longer-term declines in anticyclone frequency shown in Pepler et al. (2019); however, the overall contribution of highs to rainfall changes are smaller in this paper, as the change in the relative proportion of anticyclone vs non-anticyclone days has been captured by the decreased frequency of other weather systems we analyse.

Changes in cool season rainfall on the ESB and in Tasmania are weaker than elsewhere in southeast Australia (e.g. Fig. 1). While these regions have similar declines in cyclone and front-related rainfall to areas elsewhere in southeast Australia, there is a simultaneous increase in cool-season rainfall associated with thunderstorms, consistent with results presented by Dowdy (2020). As well as an increase in the number of thunderstorm-only days that produce rainfall, there is also an increase in the proportion of cyclones and fronts that co-occur with a thunderstorm environment in these regions, resulting in an increase in rainfall on FT and CFT days. Tasmania experienced a particularly strong increase in CFT days over the period, which are the weather 

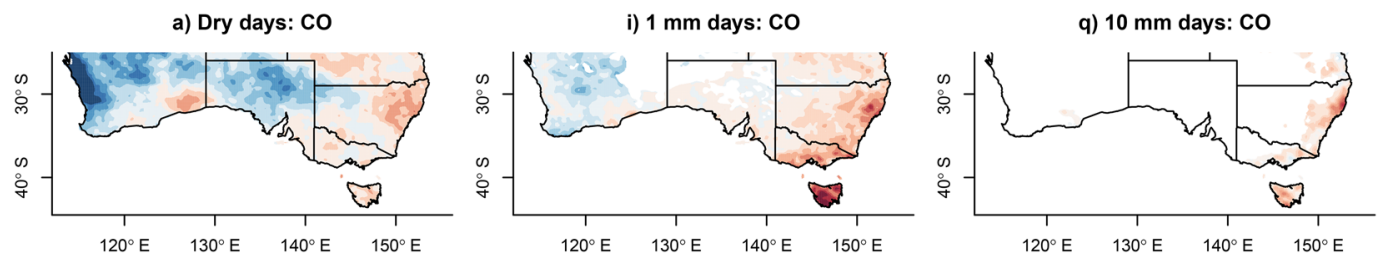

b) Dry days: FO

j) $1 \mathrm{~mm}$ days: FO

r) $\mathbf{1 0} \mathrm{mm}$ days: FO
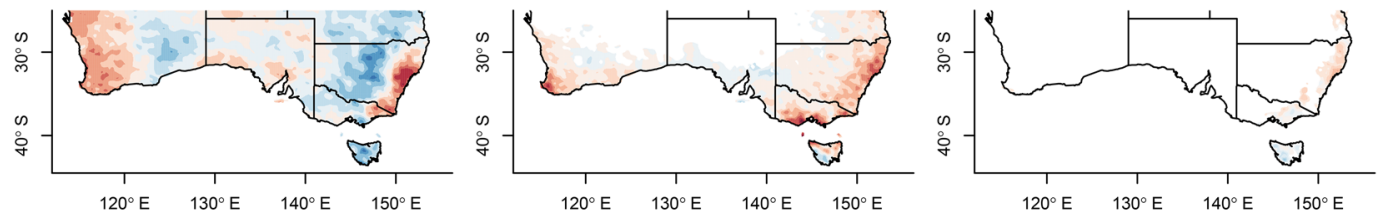

c) Dry days: $\mathrm{CF}$
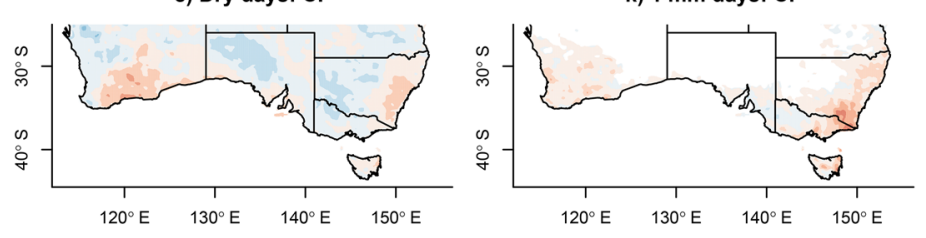

s) $10 \mathrm{~mm}$ days: $\mathrm{CF}$

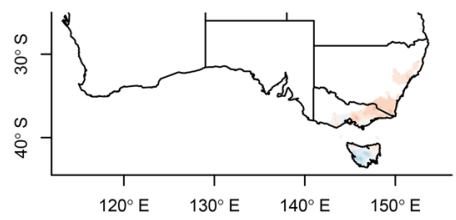

d) Dry days: TO

I) $1 \mathrm{~mm}$ days: TO

t) $\mathbf{1 0} \mathrm{mm}$ days: $\mathrm{TO}$
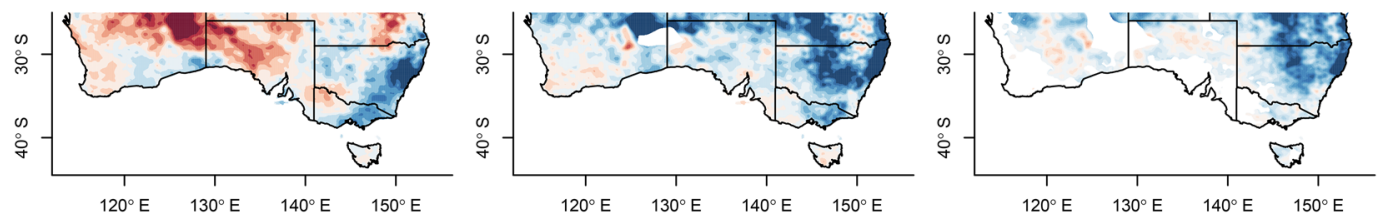

e) Dry days: CT

m) $1 \mathrm{~mm}$ days: $\mathrm{CT}$
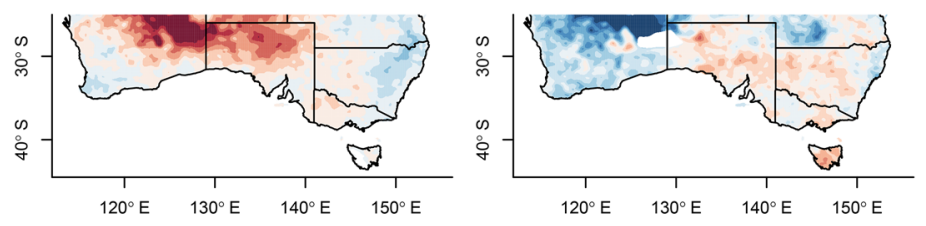

u) $10 \mathrm{~mm}$ days: CT

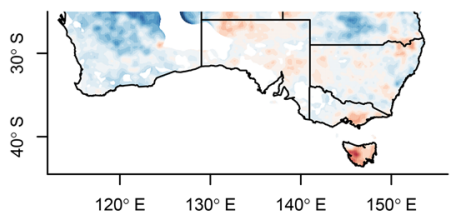

n) $1 \mathrm{~mm}$ days: FT
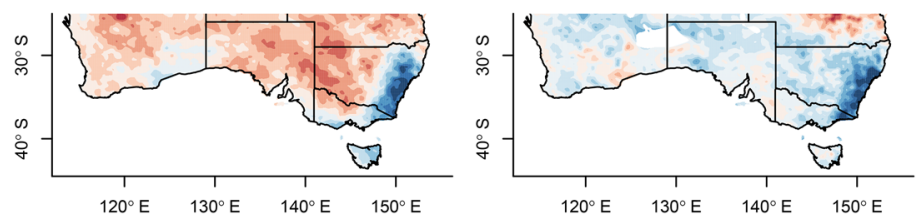

v) $10 \mathrm{~mm}$ days: FT

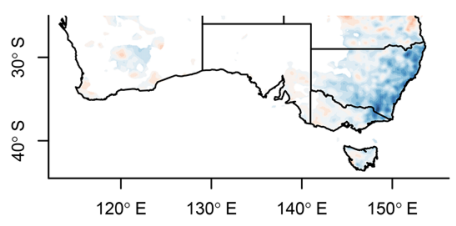

o) $1 \mathrm{~mm}$ days: CFT

w) $10 \mathrm{~mm}$ days: CFT
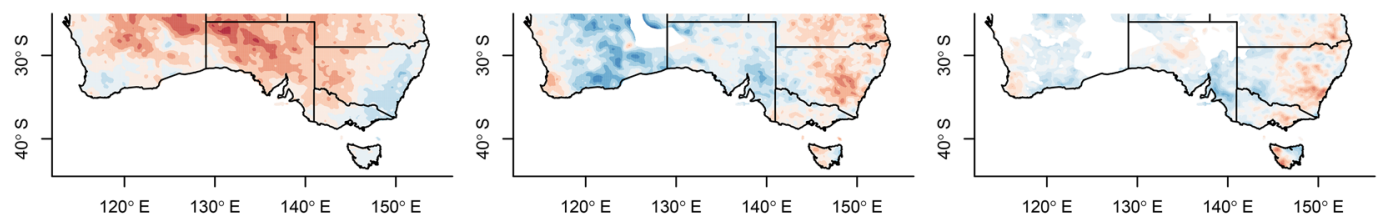

h) Dry days: Other

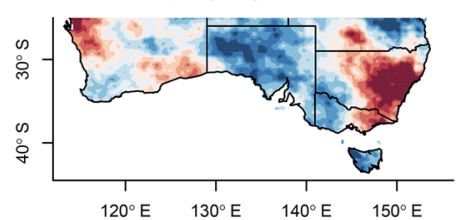

p) $1 \mathrm{~mm}$ days: Other

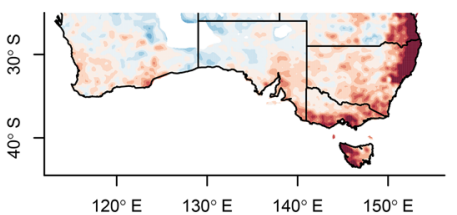

x) $10 \mathrm{~mm}$ days: Other
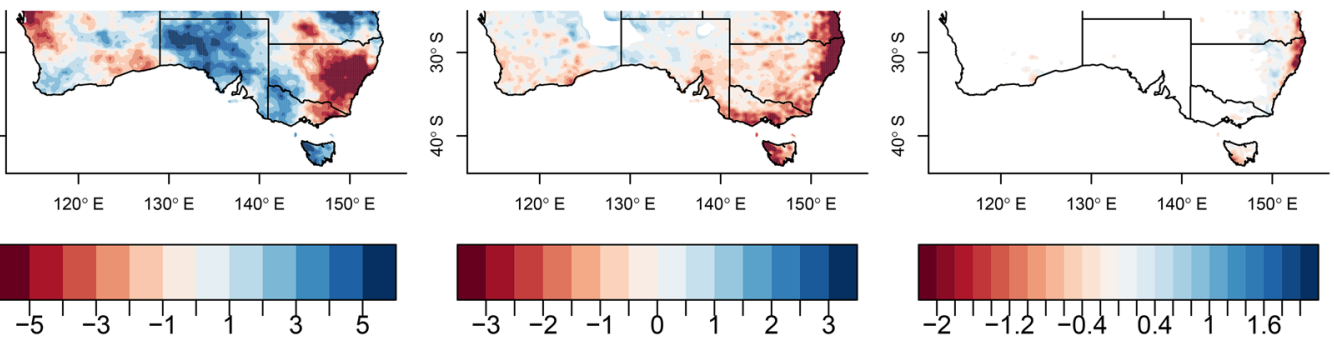
4 Fig. 7 Change in the average number of days of each weather type in November-April between 1979-1996 and 1997-2015 separated by rainfall rate: $<1 \mathrm{~mm}$ rainfall (left), $\geq 1 \mathrm{~mm}$ of rainfall (middle), $\geq 10 \mathrm{~mm}$ of rainfall (right). Colours are only shown where there is an average of at least 0.2 days/year in the 1979-1996 period, and $0.25^{\circ}$ of spatial smoothing has been added to make spatial patterns clearer

systems most likely to produce heavy rainfall (Pepler et al. 2020; Dowdy and Catto 2017).

Compared to earlier studies (Hope et al. 2006; Pook et al. 2011), we observed weaker cool season rainfall changes in SWWA than in SEA, with a statistically significant decline during May-July but not the longer May-October season. This may be because the period of SWWA rainfall declines begins in the 1960s, prior to the earliest year in our analysis. As in SEA, rainfall declines are attributed to a decline in the rainfall from cyclones and fronts, particularly a decline in the average number of days with a cyclone that produces at least $1 \mathrm{~mm}$ of rainfall.

In contrast to the clearer changes during the cool season, during the warm season November-April rainfall has increased in northern Australia, with weak but non-significant increases in rainfall in southern Australia. While there are also declines in cyclone-related rainfall in the southeast during this season, particularly on the ESB, there are larger increases in rainfall associated with thunderstorms across southern Australia, particularly from the TO and FT types. There are also increases in the average rainfall on days with thunderstorms in the warm season across large areas of southern Australia, including an increase in the number of thunderstorm days that produce at least $10 \mathrm{~mm}$ of rainfall. At the same time, throughout the year we see an increase in the frequency of dry thunderstorms, particularly on the east and southeast coasts, consistent with the results presented by Dowdy (2020). This could potentially lead to additional bushfire hazards associated with ignitions from dry lightning as an important driver for area burnt by wildfires in southeast Australia (Dowdy and Mills 2012).

Projections from global climate models consistently show a continued future decline in cool season rainfall in both SWWA and SEA (Grose et al. 2020; Hope et al. 2015). The frequency of cyclones is also expected to decline in Australian latitudes (Grieger et al. 2014; Utsumi et al. 2016), although projections of all fronts (both cold and warm) are less certain (Catto et al. 2014). In contrast, the frequency of heavy rainfall is expected to increase (Alexander and Arblaster 2017), particularly for higher-intensity and shortduration extremes that are associated with convection and thunderstorms (Westra et al. 2014; Osburn et al. 2020). The observed changes shown in this paper are consistent with these expected future changes, particularly as we have shown that there can be a decrease in the rainfall due to
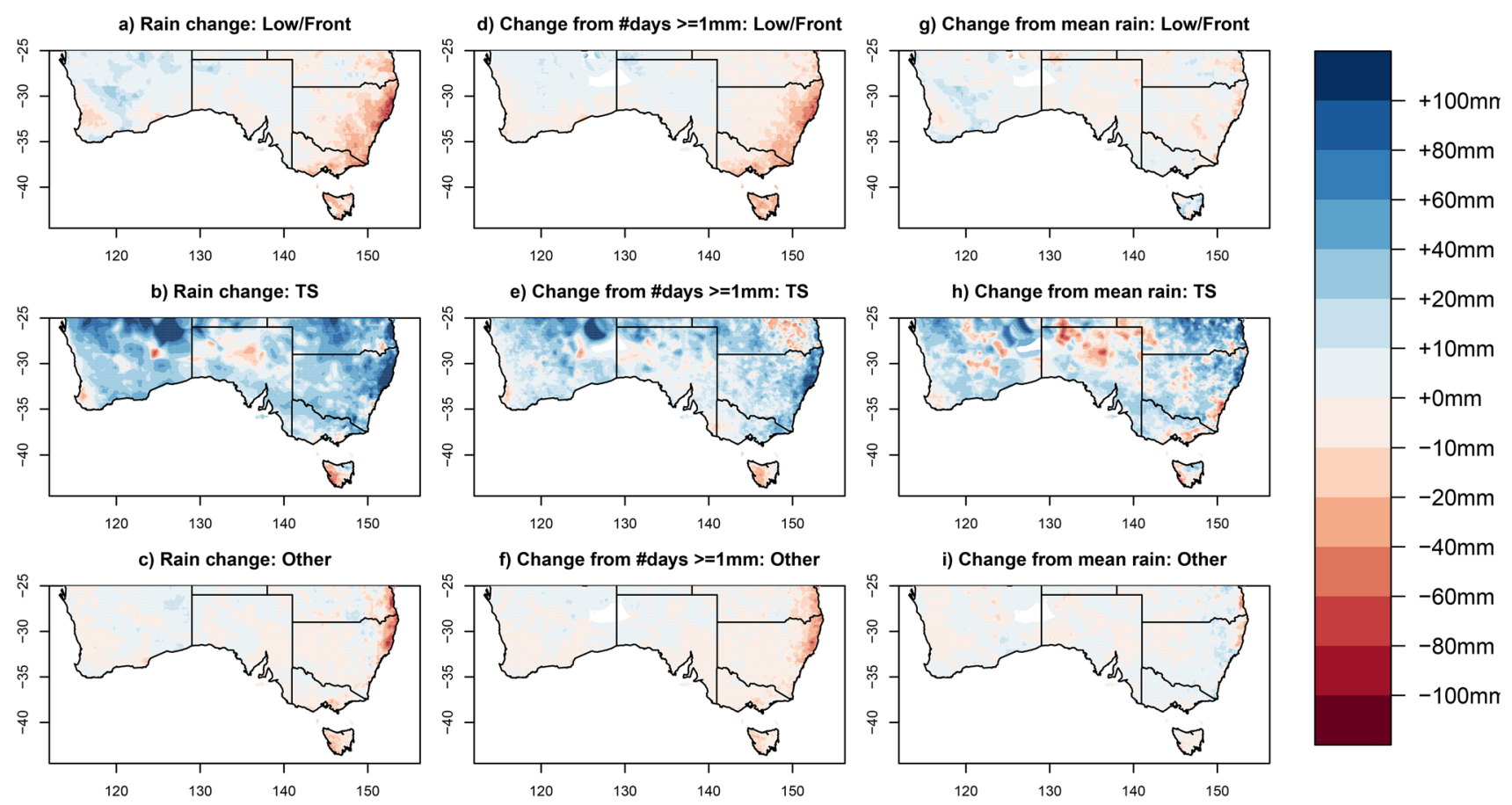

Fig. 8 November-April rainfall change (in mm) between 1979-1996 and 1997-2015 (left column), and the change divided into components from the change in frequency (central), and from change in the average rain rate on those days (right). Results are shown for the combined cyclone and front types (CO/FO/CF, top), thunderstormrelated rainfall (TO/CT/FT/CFT, middle) and Other rain (bottom) 
fronts without any change in the total number of fronts in southern Australia.

This paper shows changes in weather systems over the period 1979-2015, which is sufficient to identify significant recent changes in cool season rainfall, particularly in SEA which experienced a major drought between 1997-2009 and continued below-average cool season rainfall in subsequent years. However, the emergence of new high-quality reanalyses such as ERA5 and JRA55, and the upcoming extension of ERA5 to the period 1950-1978, will enable future work to assess the robustness of these observed changes to both the time periods used and the choice of reanalysis, particularly for southwestern Western Australia where rainfall declines begin in the late 1960s.

Acknowledgements The authors would like to thank Bertrand Timbal, Peter van Rensch and two anonymous reviewers for their measured and insightful internal reviews. We also thank Irina Rudeva and Jen Catto for their collaboration in developing the weather types dataset, including providing some of the component cyclone and front datasets, and James Risbey and Michael Pook for additional data and advice regarding cut-off lows. All authors were supported by the Victorian Department of Environment, Land, Water and Planning as part of the Victorian Water and Climate Initiative.

Funding This project is funded by the Victorian Department of Environment, Land, Water and Planning, and was assisted by resources from the Australian National Computational Infrastructure (NCI).

Code availability The cyclone, front and thunderstorm datasets used in this paper are based on a variety of pre-existing routines which are available by contacting the authors of the papers cited in the Methods section. Analysis and figures for this paper were performed using the $\mathrm{R}$ programming language.

Availability of data ERAI is available from the ECMWF at http://apps. ecmwf.int/datasets/data/interim-full-invariant/, and Australian gridded rainfall datasets are available from the Australian Bureau of Meteorology. The weather type dataset is available for research use by contacting the authors, and will be shared for research purposes as an output of the Victorian Water and Climate Initiative.

\section{Compliance with ethical standards}

Conflict of interest The authors declare that they have no conflict of interest.

Open Access This article is licensed under a Creative Commons Attribution 4.0 International License, which permits use, sharing, adaptation, distribution and reproduction in any medium or format, as long as you give appropriate credit to the original author(s) and the source, provide a link to the Creative Commons licence, and indicate if changes were made. The images or other third party material in this article are included in the article's Creative Commons licence, unless indicated otherwise in a credit line to the material. If material is not included in the article's Creative Commons licence and your intended use is not permitted by statutory regulation or exceeds the permitted use, you will need to obtain permission directly from the copyright holder. To view a copy of this licence, visit http://creativecommons.org/licenses/by/4.0/.

\section{References}

Alexander LV, Arblaster JM (2017) Historical and projected trends in temperature and precipitation extremes in Australia in observations and CMIP5. Weather Climate Extremes 15:34-56. https:// doi.org/10.1016/j.wace.2017.02.001

Barbero R, Westra S, Lenderink G, Fowler HJ (2018) Temperatureextreme precipitation scaling: a two-way causality? Int J Climatol 38:e1274-e1279. https://doi.org/10.1002/joc.5370

Bates BC, Hope P, Ryan B, Smith I, Charles S (2008) Key findings from the Indian Ocean Climate Initiative and their impact on policy development in Australia. Clim Change 89(3-4):339-354. https://doi.org/10.1007/s10584-007-9390-9

Berry G, Reeder MJ, Jakob C (2011) A global climatology of atmospheric fronts. Geophys Res Lett 38:L04809. https://doi. org/10.1029/2010GL046451

Bjerknes J, Solberg H (1922) Life cycle of cyclones and the polar front theory of atmospheric circulation. Geophys Publ 3:1-18

Catto JL, Jakob C, Berry G, Nicholls N (2012a) Relating global precipitation to atmospheric fronts. Geophys Res Lett 39(10):L10805. https://doi.org/10.1029/2012GL051736

Catto JL, Jakob C, Nicholls N (2012b) The influence of changes in synoptic regimes on north Australian wet season rainfall trends. J Geophys Res Atmos 117(10):1-9. https://doi.org/10.1029/2012J D017472

Catto JL, Nicholls N, Jakob C, Shelton KL (2014) Atmospheric fronts in current and future climates. Geophys Res Lett 41(21):76427650. https://doi.org/10.1002/2014GL061943

Catto JL, Madonna E, Joos H, Rudeva I, Simmonds I (2015) Global relationship between fronts and warm conveyor belts and the impact on extreme precipitation. J Clim 28(21):8411-8429. https ://doi.org/10.1175/JCLI-D-15-0171.1

Dee DP, Uppala SM, Simmons AJ, Berrisford P, Poli P, Kobayashi S et al (2011) The ERA-Interim reanalysis: configuration and performance of the data assimilation system. Q J R Meteorol Soc 137(656):553-597. https://doi.org/10.1002/qj.828

Dowdy AJ (2020) Climatology of thunderstorms, convective rainfall and dry lightning environments in Australia. Clim Dyn 54(0123456789):1-12. https://doi.org/10.1007/s00382-020-05167 $-9$

Dowdy AJ, Catto JL (2017) Extreme weather caused by concurrent cyclone, front and thunderstorm occurrences. Sci Rep 7:40359. https://doi.org/10.1038/srep40359

Dowdy AJ, Kuleshov Y (2014) Climatology of lightning activity in Australia: spatial and seasonal variability. Aust Meteorol Oceanogr J 64(2):103-108

Dowdy AJ, Mills GA (2012) Atmospheric and fuel moisture characteristics associated with lightning-attributed fires. J Appl Meteorol Climatol 51(11):2025-2037. https://doi.org/10.1175/ JAMC-D-11-0219.1

Dowdy AJ, Mills GA, Timbal B (2013) Large-scale diagnostics of extratropical cyclogenesis in eastern Australia. Int J Climatol 33(10):2318-2327. https://doi.org/10.1002/joc.3599

Dowdy AJ, Grose MR, Timbal B, Moise A, Ekstrom M, Bhend J, Wilson L (2015) Rainfall in Australia's eastern seaboard: a review of confidence in projections based on observations and physical processes. Aust Meteorol Oceanogr J 65(1):107-126. https://doi. org/10.22499/2.6501.008

Dowdy AJ, Soderholm J, Brook J, Brown A, McGowan H (2020) Quantifying hail and lightning risk factors using long-term observations around Australia. J Geophys Res Atmos. https://doi. org/10.1029/2020JD033101

Grieger J, Leckebusch GC, Donat MG, Schuster M, Ulbrich U (2014) Southern Hemisphere winter cyclone activity under recent and 
future climate conditions in multi-model AOGCM simulations. Int J Climatol 34(12):3400-3416. https://doi.org/10.1002/joc.3917

Grose MR, Narsey S, Delage FP, Dowdy AJ, Bador M, Boschat G et al (2020) Insights from CMIP6 for Australia's future climate. Earth's Future. https://doi.org/10.1029/2019ef001469

Guerreiro SB, Fowler HJ, Barbero R, Westra S, Lenderink G, Blenkinsop S et al (2018) Detection of continental-scale intensification of hourly rainfall extremes. Nat Clim Change 8(September):803-808. https://doi.org/10.1038/s41558-018-0245-3

Hassim MEE, Timbal B (2019) Observed rainfall trends over Singapore and the Maritime Continent from the perspective of regional-scale weather regimes. J Appl Meteorol Climatol 58(2):365-384. https ://doi.org/10.1175/JAMC-D-18-0136.1

Hawcroft MK, Shaffrey LC, Hodges KI, Dacre HF (2012) How much Northern Hemisphere precipitation is associated with extratropical cyclones? Geophys Res Lett 39:L24809. https://doi. org/10.1029/2012GL053866

Hersbach H, Bell B, Berrisford P, Hirahara S, Horányi A, MuñozSabater J et al (2020) The ERA5 global reanalysis. Q J R Meteorol Soc. https://doi.org/10.1002/qj.3803

Hope PK, Drosdowsky W, Nicholls N (2006) Shifts in the synoptic systems influencing southwest Western Australia. Clim Dyn 26(7):751-764. https://doi.org/10.1007/s00382-006-0115-y

Hope P, Timbal B, Fawcett R (2010) Associations between rainfall variability in the southwest and southeast of Australia and their evolution through time. Int J Climatol 30(9):1360-1371. https:// doi.org/10.1002/joc. 1964

Hope P, Keay K, Pook M, Catto J, Simmonds I, Mills G et al (2014) A comparison of automated methods of front recognition for climate studies: a case study in Southwest Western Australia. Mon Weather Rev 142(1):343-363. https://doi.org/10.1175/MWR-D12-00252.1

Hope P, Grose MR, Timbal B, Dowdy AJ, Bhend J, Katzfey JJ et al (2015) Seasonal and regional signature of the projected southern Australian rainfall reduction. Aust Meteorol Oceanogr J 65(1):5471. https://doi.org/10.22499/2.6501.005

Hope P, Timbal B, Hendon H, Ekström M, Potter N (2017) A synthesis of findings from the Victorian Climate Initiative. Bureau of Meteorology, Australia

Jones DA, Wang W, Fawcett R (2009) High-quality spatial climate data-sets for Australia. Aust Meteorol Oceanogr J 58(4):233-248

King AD, Alexander LV, Donat MG (2013) The efficacy of using gridded data to examine extreme rainfall characteristics: a case study for Australia. Int J Climatol 33(10):2376-2387. https://doi. org/10.1002/joc. 3588

Madonna E, Wernli H, Joos H, Martius O (2014) Warm conveyor belts in the ERA-Interim Dataset (1979-2010). Part I: climatology and potential vorticity evolution. J Clim 27(1):3-26. https://doi. org/10.1175/JCLI-D-12-00720.1

Murphy BF, Timbal B (2008) A review of recent climate variability and climate change in southeastern Australia. Int J Climat 28:859-879

Murray RJ, Simmonds I (1991) A numerical scheme for tracking cyclone centres from digital data. Part I: development and operation of the scheme. Aust Meteorol Mag 39(3):155-166

Nguyen H, Lucas C, Evans A, Timbal B, Hanson L (2015) Expansion of the Southern Hemisphere hadley cell in response to greenhouse gas forcing. J Clim 28(20):8067-8077. https://doi.org/10.1175/ JCLI-D-15-0139.1

Osburn L, Hope P, Dowdy A (2021) Changes in hourly extreme precipitation in Victoria, Australia, from the observational record. Weather Clim Extrem 31:100294. https://doi.org/10.1016/j. wace. 2020.100294

Pepler A, Dowdy A (2020) A Three-dimensional perspective on extratropical cyclone impacts. J Clim 33(13):5635-5649. https://doi. org/10.1175/JCLI-D-19-0445.1
Pepler A, Coutts-Smith A, Timbal B (2014) The role of East Coast Lows on rainfall patterns and inter-annual variability across the East Coast of Australia. Int J Climatol 34(4):1011-1021. https:// doi.org/10.1002/joc.3741

Pepler A, Hope P, Dowdy A (2019) Long-term changes in southern Australian anticyclones and their impacts. Clim Dyn 53:47014714. https://doi.org/10.1007/s00382-019-04819-9

Pepler AS, Dowdy AJ, van Rensch P, Rudeva I, Catto JL, Hope P (2020) The contributions of fronts, lows and thunderstorms to southern Australian rainfall. Clim Dyn 55(5-6):1489-1505. https ://doi.org/10.1007/s00382-020-05338-8

Pook MJ, McIntosh PC, Meyers GA (2006) The synoptic decomposition of cool-season rainfall in the southeastern Australian cropping region. J Appl Meteorol Climatol 45(8):1156-1170. https:// doi.org/10.1175/JAM2394.1

Pook MJ, Risbey JS, McIntosh PC (2011) The synoptic climatology of cool-season rainfall in the central Wheatbelt of Western Australia. Mon Weather Rev 140:28-43. https://doi.org/10.1175/MWR-D11-00048.1

Pook MJ, Risbey JS, McIntosh PC (2014) A comparative synoptic climatology of cool-season rainfall in major grain-growing regions of southern Australia. Theor Appl Climatol 117(3-4):521-533. https://doi.org/10.1007/s00704-013-1021-y

Rauniyar SP, Power SB (2020) The impact of anthropogenic forcing and natural processes on past, present and future rainfall over Victoria, Australia. J Clim 33(18):8087-8106. https://doi. org/10.1175/JCLI-D-19-0759.1

Reid KJ, Simmonds I, Vincent CL, King AD (2019) The Australian Northwest Cloudband: climatology, mechanisms and association with precipitation. J Clim 32:1-48. https://doi.org/10.1175/ jcli-d-19-0031.1

Risbey JS, Pook MJ, McIntosh PC, Ummenhofer CC, Meyers G (2009) Characteristics and variability of synoptic features associated with cool season rainfall in southeastern Australia. Int J Climatol 29(11):1595-1613. https://doi.org/10.1002/joc.1775

Risbey JS, Pook MJ, McIntosh PC (2013a) Spatial trends in synoptic rainfall in southern Australia. Geophys Res Lett 40(14):37813785. https://doi.org/10.1002/grl.50739

Risbey JS, Mcintosh PC, Pook MJ (2013b) Synoptic components of rainfall variability and trends in southeast Australia. Int J Climatol 33(11):2459-2472. https://doi.org/10.1002/joc.3597

Rudeva I, Simmonds I (2015) Variability and trends of global atmospheric frontal activity and links with large-scale modes of variability. J Clim 28(8):3311-3330. https://doi.org/10.1175/JCLID-14-00458.1

Simmonds I, Murray RJ, Leighton R M (1999) A refinement of cyclone tracking methods with data from FROST. Aust Meteorol Mag, Special Issue, 35-49

Simmonds I, Keay K, Bye JAT (2012) Identification and climatology of Southern Hemisphere mobile fronts in a modern reanalysis. J Clim 25(6):1945-1962. https://doi.org/10.1175/JCLI-D-11-00100.1

Timbal B (2010) The climate of the Eastern Seaboard of Australia: a challenging entity now and for future projections. IOP Conf Ser Earth Environ Sci 11:12013. https://doi.org/10.1088/17551315/11/1/012013

Timbal B, Drosdowsky W (2013) The relationship between the decline of Southeastern Australian rainfall and the strengthening of the subtropical ridge. Int J Climatol 33(4):1021-1034. https://doi. org/10.1002/joc.3492

Timbal B, Arblaster JM, Power S (2006) Attribution of the latetwentieth-century rainfall decline in southwest Australia. J Clim 19(10):2046-2062. https://doi.org/10.1175/JCLI3817.1

Timbal B, Arblaster J, Braganza K, Fernandez E, Hendon H, Murphy B et al (2010) Understanding the anthropogenic nature of the 
observed rainfall decline across South Eastern Australia. CAWCR Technical Report 26. http://www.cawcr.gov.au/technical-reports/ CTR_026.pdf

Utsumi N, Kim H, Kanae S, Oki T (2016) Which weather systems are projected to cause future changes in mean and extreme precipitation in CMIP5 simulations? J Geophys Res Atmos. https://doi. org/10.1002/2016JD024939

Wernli H, Schwierz C (2006) Surface Cyclones in the ERA-40 Dataset (1958-2001). Part I: novel identification method and global climatology. J Atmos Sci 63(10):2486-2507. https://doi.org/10.1175/ JAS3766.1
Westra S, Fowler HJ, Evans JP, Alexander LV, Berg P, Johnson F et al (2014) Future changes to the intensity and frequency of shortduration extreme rainfall. Rev Geophys 52(3):522-555. https:// doi.org/10.1002/2014RG000464

Publisher's Note Springer Nature remains neutral with regard to jurisdictional claims in published maps and institutional affiliations. 